\title{
THE SUSTAINABILITY OF INDONESIA PAKISTAN PALM OIL SUPPLY CHAIN
}

\author{
Diana Chalil*1, and Riantri Barus*) \\ *) Faculty of Agriculture, Universitas Sumatera Utara \\ Jl. Prof. Sofyan No.3 Kampus USU Medan 20155
}

\begin{abstract}
With high consumption and low production rates, Pakistan appears as one of the main palm oil importers in the world. Among all vegetable oils, palm oil price appears to be the lowest, thus dominating the vegetable oil import market. Indonesia and Malaysia are the two main exporters, in which Pakistan alternately imports palm oil. Within such conditions, this study aims to analyze the sustainability of Indonesia Pakistan supply chain by estimating (i) the influencing factors of Pakistan palm oil import volume from Indonesia, (ii) the price co-integration in the Indonesian-Pakistan palm oil supply chain, and (iii) the adjustments of the short run dynamics towards the long run equilibrium. Using monthly data from 2010 to 2016, the sustainability was analyzed with Auto Regressive Distributed Lag model and Vector Error Correction Model. The results show Pakistan palm oil import volume is significantly influenced by the price of Pakistan's palm oil import, trade balance and soybean oil price. The lower the palm oil import price, the higher the volume palm oil imported to Pakistan. The import price is co-integrated with all prices along the Indonesia Pakistan supply chain but no error correction towards long run equilibrium, which is partly reflecting impact of Pakistan Government interventions in palm oil trade. Based on these results, it can be concluded that price is the most influencing factor of the Pakistan palm oil import, thus Indonesia Pakistan supply chain could be sustained if the Indonesian palm oil selling price remains competitive. Therefore, Indonesian producers need to increase their productivity and reduce their production costs in all stages of the supply chain, including those among the oil palm smallholders.
\end{abstract}

Keywords: palm oil, supply chain, autoregressive distributed lag, error correction

\begin{abstract}
Abstrak: Dengan tingkat konsumsi yang tinggi dan tingkat produksi yang rendah, Pakistan menjadi salah satu importir minyak sawit utama di dunia. Diantara semua jenis minyak nabati, minyak kelapa sawit mempunyai harga yang paling rendah, sehingga mendominasi pasar impor minyak nabati. Pakistan mengimpor minyak sawit tersebut secara bergantian dari dua negara ekportir sawit utama, Indonesia dan Malaysia. Untuk menganalisis kondisi tersebut digunakan data bulanan dari tahun 2010 sampai 2016, dan diestimasi dengan model Auto Regressive Distributed Lag dan Vector Error Correction. Hasil estimasi menunjukkan bahwa volume impor minyak sawit Pakistan secara signifikan dipengaruhi oleh harga impor minyak sawit, neraca perdagangan dan harga minyak kedele. Semakin rendah harga impor minyak sawit turun maka semakin tinggi volume impor minyak sawit ke Pakistan. Harga impor tersebut terkointegrasi dengan harga-harga minyak sawit di sepanjang supply chain Indonesia Pakistan namun tidak terkoreksi menuju keseimbangan jangka panjang, yang sebagian diakibatkan oleh campurtangan Pemerintah Pakistan dalam perdagangan sawit. Berdasarkan hasil estimasi tersebut, maka dapat disarankan bahwa Indonesia perlu mempertahankan harga jual yang kompetitif di semua tahap sepanjang supply chain, termasuk di tingkat petani untuk menjaga keberlanjutan ekspor kelapa sawit ke Pakistan.
\end{abstract}

Kata kunci: kelapa sawit, supply chain, autoregressive distributed lag, error correction

\footnotetext{
${ }^{1}$ Corresponding author:

Email: diana3@usu.ac.id
} 


\section{INTRODUCTION}

With high vegetable oil consumption and low production, Pakistan appears as one of the main palm oil importers in the world. Pakistan uses most of it for food consumption such as for cooking oil and ghee. Edible oil is the main consumption of the food in Pakistan and is a key ingredient of household food consumption (Ali et al. 2013). In 2016, the Pakistan total population was 193.2 million (World Bank, 2017) with vegetable oil total domestic consumption of 2.9 million metric tons (Indexmundi, 2017). This is likely to increase as the 1990-2016 data show the stable vegetable oil consumption per capita and increasing population. The main reason of palm oil being the main oil consumption is likely that palm oil appears to be the lowest price vegetable oil, which is currently treated as the complement of palm oil (Morelli, 2008).

Besides palm oil, there are at least 6 (six) other vegetable oils i.e. soybean oil, rapeseed, sunflower seed, cotton seed, groundnuts, and copra that are traded in international markets (Oil World, 2017). Pakistan produces all of them but only with a total amount less than $30 \%$ of their total vegetable oil consumption (FAO Statistics, 2015). In addition, all of these oils are more expensive than palm oil price, giving disincentive for Pakistan to further increase their vegetable oil production. Among them, cottonseed is recorded as the main vegetable oil production, with almost $60 \%$ of Pakistan total vegetable oil production. On average, the productivity of cotton and oil palm plantations are 0.16 ton/ha and 2.65 ton/ha, respectively, while oil palm also requires less fertilizers than cotton (Bain, 2013). Such conditions make palm oil price much lower than the cottonseed price.

Indonesia and Malaysia are two main exporters, in which Pakistan alternately imports palm oil from whichever country offers the lowest prices and improvement in trade balance (Info Sawit, 2017; Alam, 2015). Malaysia palm oil export prices decreased after having Free Trade Agreement in 2007 with Pakistan, while Indonesia did so after receiving Preferential Trade Agreement in 2012 (Alam, 2015; Ismail, 2015). However, none of these have borne expected improvement in Pakistan trade balance. The primary reason for the trade deficit is the large quantity of palm oil import from Indonesia and Malaysia to Pakistan (Ismail, 2015). In general, palm oils are imported in two different types, namely, the crude and processed form with HS code 151110
(Crude Palm Oil (CPO) including vegetable oils; palm oil and its fractions, crude, not chemically modified) and 151190 (Processed Palm Oil (PPO) including vegetable oils; palm oil and its fractions, other than crude, whether or not refined, but not chemically modified). In 2005-2014, Malaysia increased its market share of crude palm oil exported to Pakistan from $60 \%$ to $96 \%$, while Indonesia decreased it from $40 \%$ to only $4 \%$. In contrast, Malaysia decreased its market share of processed palm oil exported to Pakistan from $56 \%$ to $24 \%$, while Indonesia increased it from $43 \%$ to $76 \%$ (Uncomtrade, 2017). The processed palm oil gives higher value added than the crude palm oil, so such a condition makes Malaysia loses its comparative advantage to Indonesia for processed palm oil (Salleh et al. 2016).

The wide options of vegetable oils, the government interventions in palm oil trade and the competition between Indonesia and Malaysia could lead to high fluctuations in Pakistan's palm oil demand from each exporting country, including Indonesia. Currently, Indonesia exports more than $70 \%$ of its palm oil total production and recorded as the highest export income contributor (Statistics Indonesia, 2015). This is likely stemmed from the low selling price of Indonesia palm oil. Therefore, this study assumed that if the price could remain competitive, the Indonesia Pakistan palm oil supply chain could be sustained. Such hypothesis will be tested by analyzing (i) the influencing factors of Pakistan palm oil import volume from Indonesia (ii) the price co-integration in the Indonesian-Pakistan palm oil supply chain and (iii) the adjustments of the short run dynamics towards the long run equilibrium. Results of this study are expected to provide robust information for policy makers in maintaining Pakistan as a significant importer for Indonesian palm oil.

\section{METHODS}

Using the monthly data from 2010-2016, stationarity of each variable was tested using the Augmented Dickey Fuller test using the following equation.

$$
\Delta \mathrm{Y}_{1}=\alpha+\rho \mathrm{Y}_{\mathrm{t}-1}+\sum_{\mathrm{i}=1}^{\mathrm{n}} \gamma \mathrm{Y}_{\mathrm{t}-\mathrm{j}}+\mu_{1}
$$

$Y_{t}$ is the series data from Indonesia and Pakistan, $\rho$ is the tested coefficient and $\mathrm{j}$ is the lag length chosen from ADF test. The null hypothesis is $Y_{t}$ has a unit root. Unit root test and co-integration are tested with Autoregressive Distributed Lag Model (ARDL), which 
could be used if the variables included in the equations are stationer at different levels (Researchgate, 2017)

$$
\mathrm{Y}_{\mathrm{t}}=\sum_{\mathrm{i}=1}^{\mathrm{p}} \alpha_{\mathrm{i}} \mathrm{Y}_{\mathrm{t}-\mathrm{i}}+\sum_{\mathrm{i}-1}^{\mathrm{n}} \mathrm{C}_{\mathrm{i}} \mathrm{X}_{\mathrm{t}-1}+\varepsilon_{\mathrm{t}}
$$

In general, a constant is included in Equation (1). Estimation of influencing factors of the volume of Pakistan's palm oil import from Indonesia ( $Q_{M}^{P P O}$ ) includes the price of Pakistan's palm oil import from Indonesia ( $\left.P_{M}^{P P O . I n d}\right)$, the price of Pakistan's palm oil import from Malaysia ( $P_{M}^{\text {PPO.Malay }}$, the price of Pakistan's soybean oil import $\left(\mathrm{P}_{M}^{S o y}\right)$, Indonesia-Pakistan bilateral trade balance (TB) and exchange rate (ER). Pearson Correlation was used to test multicollinearity between these influencing factors. The data were collected from International Trade Statistics Database (UN Comtrade), FAO, Statistics Indonesia (BPS), PASPI monitor, and Plantation Office (Dinas Perkebunan) of North Sumatra Province. The entire price data were measured in USD/ $\mathrm{kg}$, the import volume was measured in thousand metric tons, and trade balance was measured in million USD. HS Code 151190 was used because Pakistan imports this type of palm oil continuously from Indonesia. Ramsey RESET Test was used to test the linearity specification of the following equation.

$$
Q_{M}^{P P O}=f\left(P_{M}^{P P O . I n d}, P_{M}^{P P O . M a l a y}, P_{M}^{\text {Soy }}, T B, E R\right)
$$

Using ARDL approach, co-integration between prices along the supply chain is estimated for each level of the markets, namely, (i) Pakistan retail price ( $Q_{R}^{\text {CO.Pak }}$ ) and $\left(Q_{R}^{\text {Ghee.Pak }}\right)$ and Pakistan import price $\left(Q_{M}^{P P O . I n d}\right)$, (ii) Pakistan import price ( $\left.Q_{M}^{\text {PPO.Ind }}\right)$ and Indonesian export price $\left(Q_{X}^{\text {CPO.Ind }}\right)$, (iii) Indonesian export price ( $Q_{X}^{\text {CPO.Ind }}$ ) and Indonesian local mill price $\left(Q_{\text {Sumut }}^{C P O}\right)$, (iv) Indonesian local mill price ( $Q_{\text {Sumut }}^{\text {CPO }}$ ) and Indonesian smallholder price ( $Q_{S S H}^{F F E}$ ) and ( $Q_{I S H}^{F F E}$ ). Cooking oil and vegetable ghee are used to represent the end consumer products in Pakistan as it uses palm oil as its main component raw material. Belawan free on board (FOB) price, one of the normally quoted as benches palm oil prices, is used as the representative of Indonesian export price (commoditybasis.com, 2017). Smallholders' prices are differentiated between schemed and independent groups as in general the former receives Disbun (Plantation Office) prices, while the latter depends on their bargaining power (Chalil and Barus, 2013; Chalil and Barus, 2016).

The co-integrated prices in the Indonesia-Pakistan supply chain are then further estimated with VECM in order to analyze the short run dynamic and adjustment time needed to reach the long-run equilibrium. The estimations use two scenarios, with and without constant to evaluate the possibility of absolute convergence. The VECM equations run separately for each of the cointegrated price. VECM is used to analyze the speed of adjustment of such integration.

$$
\Delta \mathrm{Y}_{\mathrm{it}}=\alpha_{\mathrm{i}}+\sum_{\mathrm{j}=1}^{\mathrm{n}} \beta_{\mathrm{i}} \Delta \mathrm{Y}_{\mathrm{jt}-1}+\gamma_{\mathrm{i}} \varepsilon_{\mathrm{it}}+\varepsilon_{\mathrm{t}}
$$

$\varepsilon_{\mathrm{it}}$ is the residual series that $\varepsilon_{\mathrm{it}}=\mathrm{Y}_{\mathrm{it}-1}-\alpha_{\mathrm{i}}-\beta_{\mathrm{i}} \mathrm{Y}_{\mathrm{jt}-1}$, and $\gamma_{\mathrm{i}}$ shows the speed of adjustment. Short-run dynamics from the non-stationary series is shown by $\beta_{i}$, which will be adjusted towards the Long Run Equilibrium if $\gamma_{i}<0$. The more negative $\gamma_{1}$ the faster the series converge to the Long Run Equilibrium.

\section{RESULTS}

The Augmented Dickey Fuller unit root test results (Table 1) show that Indonesia palm oil import volume and Indonesia Pakistan trade balance series are stationary at $\mathrm{I}(0)$, while the remaining variables are $\mathrm{I}(1)$.

It is shown that there is a High Pearson Correlation between trade balance and Indonesian palm oil import price; therefore, exchange rate series are excluded from the equation estimations. Similarly, the price of Pakistan's palm oil import price from Malaysia is highly correlated with that from Indonesia. Ramsey RESET resulted in F test (1.01) less than F stat (3.13) and justified the usage of linear specification in the ARDL model. F-Bounds and t-Bounds Tests with 9.46 and -6.13 values, respectively, reject the "No level relationship" null hypothesis. With this co-integrated result, influencing factors of Pakistan palm oil import from Indonesia can be estimated using the ADRL result (Table 2).

The ADRL estimation results reveal that the price of Pakistan's palm oil import from Indonesia and the price of Pakistan's soybean oil import significantly influence the volume of Pakistan's palm oil import from Indonesia. All the coefficient signs are as expected. The price of Pakistan's palm oil import from Indonesia has the greatest influence on the volume of Pakistan's palm oil import from Indonesia. Each dollar per kg decrease in the price will increase 124.34 ton of the Pakistan's palm oil volume import. This macro level fact is in 
accordance with the micro level condition. Utilizing the primary data from 150 respondents in Faisalabad city in 2012, Ali et al (2012) found that edible oil prices significantly influence edible oil consumption. Edible oil price reduction will increase the level of consumption, although the changes tend to be inelastic as it is the main consumption of food in Pakistan. The soybean oil import price positive sign shows its role as a substitute for palm oil. Each dollar per $\mathrm{kg}$ increase in soybean oil import price will increase 37.27 tons per month of the volume of Pakistan's palm oil import from Indonesia. However, the substitution is really inelastic; from 2010-2016, on average, Pakistan palm oil import volume was 84 thousand tons per month, while the average price was USD0.87 per $\mathrm{kg}$ (UNComtrade, 2017).

A month lag of Indonesia-Pakistan trade balance positively influences the volume of Pakistan's palm oil import from Indonesia. A million USD lag trade balance increase will raise 400 tons of the volume of Pakistan's palm oil import from Indonesia. Pakistan government consistently attempts to improve their trade balance with various interventions and policies, including the signing of Preferential Trading Agreement (PTA) for palm oil product from Indonesia. The PTA decreases the palm oil price which at the end increases the palm oil import volume. However, it is unlikely to be effective, indicating by the high and fluctuating Indonesian net import to Pakistan. On average, from January 2010 December 2016, the Indonesia-Pakistan import export ratio to Indonesia balance was approximately 0.14 per month, with 0.02 and 0.67 of minimum and maximum ratio, respectively. Similarly, previous Pakistan palm oil import also positively influenced the import volume; a thousand tons of increase in the previous volume of Pakistan's palm oil import from Indonesia will increase 350 tons of that of the current volume.

In fact, such condition would not only affect Indonesian palm oil exporters and big companies producers but also smallholders that currently tend to be an important part of the Indonesia Pakistan palm oil global supply chain. Trace and Maximum Eigenvalue values in each of the markets that range from 2.74 to 34.92 and 0.04 to 0.29 , respectively with probability values range from 0.01 to 0.06 reveal that prices are co-integrated along the supply chain from the Pakistan retail cooking oil and vegetable ghee prices to schemed smallholders' prices.
However, while the lag of co-integration between the cooking oil or ghee prices, Pakistan import prices and Belawan (Indonesia) FOB prices are only 2 lags, and co-integration between Indonesia local mill prices and smallholders'prices takes 4 lags. Moreover, independent smallholders' price does not co-integrate with local mill prices. Comparing to smallholders' individual average production, on average, the mill capacities are very big. Smallholders harvest their FFB every two weeks, with average production of 1-2 tons per harvest per smallholder. FFB are sold to palm oil collectors, who then re-sell it to the mills. The mills process the FFB every day, with an average of 20 working hours and capacity of 30,40 , or 60 tons per hour. Smallholders receive prices based on the mill buying prices minus all marketing costs, including transportation costs. Since smallholders' plantation locations are scattered, transportation costs among smallholders are also varied. Moreover, village collectors do not conduct sortation when buying smallholders' FFB, but district collectors (RAM) and mills do so. Mills randomly test the oil content as a base for purchasing smallholders' FFB. All of these reveal the low variation in the individual palm oil mills, but very high variations in the individual smallholders. All of this might partly explain the relatively long lag of co-integration between crude palm oil local prices and schemed smallholder prices, and even there is no co-integration between crude palm oil local prices and independent smallholder prices.

The co-integration of cooking oil or ghee and palm oil prices reflect the fact that palm oil still constitutes the main raw material utilized in these products, which are traditionally consolidated in Pakistan society (Morelli, 2008). Unlike other vegetable oils that specifically stated the main raw material of oil on the cooking oil or ghee packages, a number of cooking oil or ghee products only put vegetable oil in general for those that use palm oil as the main ingredient. Consumers choose the palm cooking oil and ghee more because of their relatively low prices. However, not all of the cointegrated prices converge to a long-run equilibrium. Lederman et al. (2003) explained that co-integration between economies is necessary but not a sufficient condition for absolute converges, which is supported by a zero constant. In this case, estimation results of the 4 VECM equations in the co-integrated series are as follows. 
Within zero constant, all adjustment coefficients are still not significant; thus, null hypothesis of zero adjustment coefficients cannot be rejected. This means that prices along the Indonesia Pakistan palm oil supply chain are not error correcting and do not respond to the discrepancy from the long run equilibrium (Masih and Masih, 1998; Ndahiriwe and Gupta, 2010). The estimation results also indicate some disturbances in the stability of the equilibrium, displayed by the negative adjustment coefficients and lags in the co-integrating equations. However, with the zero adjustment coefficient, it can be said that the disturbances would not be corrected by prices from other sequence markets along the supply chain. Such condition might partly stem from the government interventions that could obscure market signals. Currently, with alternative palm oil sources from Malaysia, Pakistan Government still asks for an improvement in their deficit trade balance with Indonesia (Alam, 2015, Ismail, 2015). Estimation results (Table 2) show that trade balance significantly influences the volume of Pakistan's palm oil import from Indonesia.

\section{Managerial Implications}

Selling price as the most influencing factors for the Pakistan import volume, the sustainability of IndonesiaPakistan palm oil supply chain could be established if the existing competitive condition of Indonesia palm oil can be maintained in the future. With co-integrated prices, such competitive condition could only be achieved if all of the Indonesian producers are involved along the supply chain, especially in improving productivity of smallholders, so that the production costs could remain low.

\section{CONCLUSIONS AND RECOMMENDATIONS}

\section{Conclusions}

Indonesia - Pakistan supply chain is cointegrated from the import price up to the grower price. The import price increases from time to time, which is mostly influenced by the trading price. The lower the import price is, the higher the import volume will be. Palm oil export competes with other vegetable oils in the international market. In fact, from 1997 to 2017, palm oil prices have always appeared as the lowest among all other vegetable oils (Oilworld in Indexmundi, 2017). In addition, Indonesian palm oil export prices to Pakistan were also always lower than the Malaysian (UNComtrade, 2017). Therefore it can be concluded that the sustainability of Indonesian-Pakistan supply chain would be maintained.

\section{Recommendations}

Indonesian palm oil industry needs to improve inefficient growers, processors or exporters' production and marketing cost efficiency to maintain the competitiveness of export prices. Independent palm oil smallholders appear to be one of the most inefficient growers. Therefore, extra programs in improving independent productivity are still needed.

\section{ACKNOWLEDGEMENTS}

The research was funded by the Research Center of Universitas Sumatera Utara in accordance with TALENTA of Universitas Sumatera Utara Research Contract 2017 Number: 5338/UN5.1. R/PPM/2017 dated 22 Mei 2017.

\section{REFERENCES}

Alam K. 2015. Pakistan's FTAs have borne no fruit so far. the express tribune Pakistan. https://tribune. com.pk/story/935097/pakistans-ftas-haveborne-no-fruit-so-far/ [1 August 2017].

Ali Z, Aslam M, Rasool S. 2013. Factors affecting consumption of edible oil in Pakistan. IOSR Journal of Business and Management 15(1):8792. https://doi.org/10.9790/487X-1518792.

Bain B. 2013. Role of fertilizers in increased agricultural productivity. FERTECON Limited. Seville:IATRC Symposium.

Chalil D, Barus R. 2013. Willingness to pay and benefit cost analysis in implementing rspo principle and criteria. Research Report. National Strategic Fund (Hibah Strategis Nasional).

Chalil D, Barus R. 2016. Crude palm oil market integration and the impact on smallholders' income. Research Report. National Strategic Fund (Hibah Strategis Nasional).

CommodityBasis. 2017. Palm oil prices. https://www. commoditybasis.com/palmoil_prices. [7 August 2017].

Eviews. 2017. Vector Error Cirrection (VEC) Models. http://www.eviews.com/help/helpintro. 
$\mathrm{html}$ page/content/VAR-Vector_Error Correction_(VEC)_Models.html.[7 August 2017].

Indexmundi. 2017. Pakistan palm oil domestic consumption by year. https://www.indexmundi. com/agriculture/?country $=p k \&$ commodity $=$ palm-oil\&graph=domestic-consumption. [19 November 2017].

Info Sawit. 2017. http://palmoilmagazine.com/mobile/ index.php/news/detail/balance-deficit--pakistanasked-for-indonesia-to-do-more-imports.[1 August 2017].

Ismail MN. 2015. Trade deficit forces MoC to review PTA with Indonesia. Economic and Industry Development Division, Malaysian Palm Oil Board (MPOB). http://bepi.mpob.gov.my/news/ detail.php?id=19508. [1 August 2017].

Lederman D, Maloney WF, Serven L. 2003. Lessons from NAFTA for Latin America and the Caribbean Countries: A Summary of Research Findings. Washington: The World Bank.

Masih AMM, Masih R. 1998. Long and shortterm dynamic causal transmission amongst international stock markets. School of Finance and Business Economics Working Paper Series.

Morelli G. 2008. Edible Oils in Pakistan an Overview
With a Focus On Olive Oil. Florence: Istituto Agronomico per l'Oltremare.

Ndahiriwe K, Gupta R. 2010. Temporal causality between taxes and public expenditures: the case of South Africa. The Journal of World Economic Review 6(1):87-100.

Oil World. 2017. Global Oil Supply, Demand and Price Outlook With Special Emphasis on Palm Oil. Hamburg: Global Market Research on Oilseeds, Oils and Meals.

Researchgate. 2017. Cointegration testing?. https:// www.researchgate.net/post/Cointegration testing [17 July 2017].

Salleh KM, Abdullah R, Ab Rahman, MAK, Balu N, Nordin AZA. 2016. Revealed comparative advantage and competitiveness of Malaysian palm oil exports against indonesia in five major markets. Oil Palm Industry Economic Journal 16(1):1-7.

[UNComtrade]United Nations International Trade Statistics Database. 2017. https://comtrade. un.org/monthly/Main/Data.aspx. [23 May 2017].

Worlbank. 2017. https://data.worldbank.org/country/ pakistan. [19 November 2017]. 